\title{
Bio Medical Waste Generation and Management Practices in V.S.S. Medical College \& Hospital, Burla, Odisha, India
}

\author{
M.R.Mahananda
}

P.G. Department of Environmental Sciences, Sambalpur University, India

Copyright $@ 2015$ Horizon Research Publishing All rights reserved.

\begin{abstract}
Background: An important issue of environmental protection process is the solid waste management that includes responsible planning of collecting, transporting, processing and disposing of hazardous and non-hazardous solid waste material. The health of public, patients and professionals alike are affected by poor waste management practices. The study highlights a holistic approach of biomedical waste management with regards to the chain of environmental and health risks and concerns aimed in achieving the fundamental premises for a systemic approach of biomedical waste management. An attempt has been made to critically review the current management practices adopted in V.S.S. Medical college \& Hospital. Following the Rules and Regulation the methods for segregation, packaging, labeling and the treatment techniques for reduction in volume, neutralization and final disposal of the biomedical waste are analysed. Methods: Personal observations of the waste treatment and disposal practices and Assessment of knowledge, attitude and practices of working personnel with the help of questionnaires were followed in this study. The information obtained has been confirmed by means of direct spot visit. The views and suggestions of working personnel over existing conditions/methods of biomedical waste management in the hospitals were also recorded. The information obtained was later confirmed by means of direct observations. Results:There are 20 units having total bed capacity of 1006 . The daily generation of category $1 \& 2$ is $40-50 \mathrm{~kg} / \mathrm{day}$. The daily generation of category 3 waste is $2-3$ $\mathrm{kg}$ which was measured one day after one day. Category $4 \& 5$ waste generation amounting $30-40 \mathrm{Kg} /$ day. The Solid waste, (category 6) generation amounting $80-90 \mathrm{~kg} /$ day. The solid waste, category 7 waste generation is $30-40 \mathrm{~kg} /$ day. Waste generated from laboratory (category,8) was estimated and found to be 30-40 litres/ day and the incineration ash category 9 generation was recorded as $3-4 \mathrm{Kg} /$ day. The chemical waste category 10 was not properly assessed by the CBWTF.The current segregation practice is not that efficient in reducing the waste going to incinerator. According to the opinion of employees at V.S.S.Medical College and hospital burla, the important reasons for the improper segregation of wastes are; inappropriate location of waste bins, waste bins
\end{abstract}

being full and lack of knowledge regarding the constituents of medical waste. Conclusion: The performance of CBWTF can be enhanced with cooperative efforts of BMW generators possible if a healthy co-ordination exists between CBWTF and BMW generators.

Keywords CBWTF, Biomedical Waste, Incinerator, Shredder, Microwave

\section{Background}

Many strides have been made in the field of health care system over the years. Ironically, along with restoring and maintaining community health, health care settings also threatened their well-being. The health of public, patients and professionals alike are affected by poor waste management practices [1]. In addition to this, it also contributes to environmental degradation. In 1983, a meeting was held at Bergen, Norway. The meeting was convened by the World Health Organization (WHO) regional office for Europe. The Biomedical waste management issue was first discussed during this meeting. Now, years later, this has turned into a global humanitarian issue.

Current Waste Management practices are characterized by poor quality collection service and improper disposal at open dumpsites. Hospital, hazardous and household wastes are mixed together at site. Recoverable wastes, paper and glass are destroyed than separated and recycled for economic use.

Uncontrolled burning of medical wastes may pollute the air with acidic gases, dioxins, furans and heavy metals [2]. A clear relationship between the burning of chlorinated organic chemical products and wastes, especially PVC and dioxin emissions from combustion facilities was reported by a host of studies conducted at the University of Florida[3,4,5,6,7,8]. A number of common initiatives to manage heath care waste are reported from developed countries. Most of the western nations had common incinerators, which are now banned in some of the developed countries. The shifting from burning to non-burning technology is being undertaken in a phased manner [9]. Paul Carnet reported that a number centralized 
treatment and disposal facilities for hospital wastes existing in USA in Canada. The technology used in combination of incineration and landfill.

Incineration utilizes thermal energy to decline waste materials to non-combustible residue or ash and exhaust gases [10]. The Fly and bottom residues produced after medical waste incineration contain high level of heavy metal like $\mathrm{Pb}, \mathrm{Cd}, \mathrm{Ni}, \mathrm{Cr}, \mathrm{Cu}$ and $\mathrm{Zn}$. However, despite of public concerns about incinerators, it is the most frequently used option, due to its advantages regarding the sterilization of pathological and anatomic waste, volume and mass reduction, and energy recovery [11]. Autoclaving/sterilization is the second most commonly used waste disposal technology. The process involves steaming the waste materials at lethal temperatures to penetrate and potentially kill pathogens[12]. Autoclave is viewed as a more costly method than incineration [13]. One of the major disadvantages of autoclave pointed out is that it doesn't reduce the size of waste fed in to the system. The treated waste then has to go to the landfill sites which again cause many environmental threats. Many studies shows that a shredder incorporated with an autoclave can be the best option to treat the medical waste [12].

The microwave process utilizes the radiant energy to kill infectious agents by converting radiant energy to heat and pressure. Shredding is usually combined with microwave technology. A combined on site Microwave - small scale incinerator technology is the most cost effective and environmental friendly treatment technology [14].The disinfection efficiency of microwave can be a performance issue for microwave [15]. In chemical treatments, chemicals like chlorine, formaldehyde, ethylene oxide etcetera are used as disinfectants. Again the effectiveness of disinfection is questioned as it is dependent on the temperature, $\mathrm{pH}$ and surface area [15]. None of the alternative technologies are totally risk free, they can be combined with an effective program of waste reduction and segregation to reduce the environmental impacts and financial cost of medical waste disposal. The criteria's used to evaluate technological option should consider environmental, health and economic factors [16]. The best technology for the medical waste treatment will be different for different hospitals. It may depend on the local conditions and the requirement of the hospital.

For selecting the most efficient treatment method of hospital wastes, the composition analysis is considered to be the fundamental information. Currently there is no information done regarding the characteristics biomedical waste generated in V.S.S.Medical College and Hospital. With the above background the present study was carried out to assess the quantum of biomedical waste generation as well as the present state of management practices in the hospital.

\section{Materials and Methods}

Personal observations of the waste treatment and disposal practices $[17,18,19]$ and Assessment of knowledge, attitude and practices of working personnel with the help of questionnaires were followed in this study $[20,21,22,23,24,25]$. A questionnaire was prepared that included questions regarding number of inpatients/day, outpatients/day, number of beds (total), awareness about biomedical waste(management and handling) rules, 1998, categories of biomedical waste produced and estimated quantity ( $\mathrm{kg} / \mathrm{day})$, waste segregation, collection, labeling, transport and disposal, financial and personal resources. The information obtained has been confirmed by means of direct spot visit. The views and suggestions of working personnel over existing conditions/methods of biomedical waste management in the hospitals were also recorded. The information obtained was later confirmed by means of direct observations.

\section{Results}

Table1. The number of facilities and beds available in V.S.S. Medical College Burla.

\begin{tabular}{|c|c|c|}
\hline Sl. No. & Name of the Department & No. of Beds \\
\hline 1 & Medicine & 180 \\
\hline 2 & Surgery & 180 \\
\hline 3 & Paediatrics & 90 \\
\hline 4 & Orthopaedics & 30 \\
\hline 5 & Pulmonary Medicine & 50 \\
\hline 6 & Skin and VD & 36 \\
\hline 7 & Opthalmology & 60 \\
\hline 8 & E. N.T. & 38 \\
\hline 9 & Radiotherapy & 24 \\
\hline 10 & Cardiology & 20 \\
\hline 11 & Psychiatry & 20 \\
\hline 12 & Neurology & 20 \\
\hline 13 & Dental & 02 \\
\hline 14 & Urology & 20 \\
\hline 15 & Nephrology & 20 \\
\hline 16 & Infectious Ward & 04 \\
\hline 17 & Neurosurgery & 20 \\
\hline 18 & Obestric \& Gynecology & 150 (including PPC 10) \\
\hline 19 & Paying Cabin & 18 \\
\hline 20 & SNCU Unit & 24 \\
\hline & Total & 1006 \\
\hline & & \\
\hline
\end{tabular}

In the endeavour undertaken by the CBWTF, different category of waste coming to central biomedical waste management facility (CBWTF) the daily generation of category $1 \& 2$ is $40-50 \mathrm{~kg} / \mathrm{day}$. The daily generation of category 3 waste is $2-3 \mathrm{~kg}$ which was measured one day after one day. Category $4 \& 5$ waste generation amounting 30-40 $\mathrm{Kg} /$ day. The Solid waste, (category 6 ) generation amounting $80-90 \mathrm{~kg} /$ day. The solid waste, category 7 waste generation is $30-40 \mathrm{~kg} /$ day. Waste generated from laboratory (category,8) was estimated and found to be 30-40 litres/ day and the incineration ash category 9 generation was recorded as $3-4 \mathrm{Kg} /$ day with a bed capacity of 1006 having 20 different units. Number of beds in different treatment units has been depicted in Table 1. Whereas, the chemical waste category 10 was not properly assessed by the CBWTF. 
The Central Biomedical Waste Management Unit of V.S.S. Medical College Burla collect the biomedical waste generated daily from each unit quantify and maintained the record in a prescribed format. (Table $2 \mathrm{a} \& \mathrm{~b}$ ). From the record it was observed that the CBWTF collect the waste in three different colour coded bags i.e. Yellow, Red and Black.
Simultaneously, the sharp wastes are collected in punctured proof carry bags. During the investigation it was found that on an average the hospital including all the units itself generated $8 \mathrm{~kg}$ /day of waste collected in Yellow bag, 58.3 $\mathrm{kg} /$ day in Red bags, $132.5 \mathrm{~kg} /$ day in Black bags and $53.7 \mathrm{~kg}$ /day in ppc.

Table2a. Waste generated at different units per day at V.S.S. Medical College Burla.

\begin{tabular}{|c|c|c|c|c|c|c|c|c|c|c|c|}
\hline \multirow{2}{*}{$\begin{array}{c}\text { Generating } \\
\text { Points/Hospital wards }\end{array}$} & \multicolumn{3}{|c|}{ No. of Bags } & \multicolumn{4}{|c|}{ Wt. in $\mathrm{KG}$} & \multirow{2}{*}{ Occupancy } & \multirow{2}{*}{$\begin{array}{l}\text { Segregated/M } \\
\text { utilated }\end{array}$} & \multirow{2}{*}{$\begin{array}{l}\text { Handed over } \\
\text { to BMW }\end{array}$} & \multirow{2}{*}{ Signature } \\
\hline & $\mathbf{Y}$ & $\mathbf{R}$ & B & $\mathbf{Y}$ & $\mathbf{R}$ & B & PPC & & & & \\
\hline MMW I/II/III/IV & & 3 & 3 & & 1.44 & 4.22 & 00 & $\mathrm{x}$ & $\mathrm{x}$ & $\mathrm{x}$ & $\mathrm{x}$ \\
\hline Neurology-M/V/VI & & & & & & & & $\mathrm{x}$ & $\mathrm{x}$ & $\mathrm{x}$ & $\mathrm{x}$ \\
\hline $\begin{array}{c}\text { FMW- } \\
\text { Neurology-F }\end{array}$ & & 2 & 1 & & 1.5 & 16 & 8.0 & $\mathrm{x}$ & $\mathrm{x}$ & $\mathrm{x}$ & $\mathrm{x}$ \\
\hline Cardiology-F & & & & & 0 & 0 & 0 & $\mathrm{x}$ & $\mathrm{x}$ & $\mathrm{x}$ & $\mathrm{x}$ \\
\hline Nephrology-F & & & & & 0 & 0 & 0 & $\mathrm{x}$ & $\mathrm{x}$ & $\mathrm{x}$ & $\mathrm{x}$ \\
\hline Cardiology-M \& ICU & & 2 & 2 & & 0.1 & 2.0 & 3.0 & $\mathrm{x}$ & $\mathrm{x}$ & $\mathrm{x}$ & $\mathrm{x}$ \\
\hline $\begin{array}{c}\text { Nephrology-Male\& } \\
\text { Dialysis }\end{array}$ & & 5 & 5 & & 0.5 & 1 & 0.2 & $\mathrm{x}$ & $\mathrm{x}$ & $\mathrm{x}$ & $\mathrm{x}$ \\
\hline Male Surgical I/II/III/IV & & 6 & 3 & & 5 & 8 & 5 & $\mathrm{x}$ & $\mathrm{x}$ & $\mathrm{x}$ & $\mathrm{x}$ \\
\hline Female Surgical & & 2 & 1 & & 1.0 & 2.0 & 1.0 & $\mathrm{x}$ & $\mathrm{x}$ & $\mathrm{x}$ & $\mathrm{x}$ \\
\hline Surgery-Main O.T. & 1 & 2 & 2 & & 1.0 & 1.5 & 0.1 & $\mathrm{x}$ & $\mathrm{x}$ & $\mathrm{x}$ & $\mathrm{x}$ \\
\hline Emergency O.T & 1 & 2 & 2 & & & & & $\mathrm{x}$ & $\mathrm{x}$ & $\mathrm{x}$ & $\mathrm{x}$ \\
\hline Burn Unit & 1 & 1 & 1 & & 1.5 & 2.5 & & $\mathrm{x}$ & $\mathrm{x}$ & $\mathrm{x}$ & $\mathrm{x}$ \\
\hline $\begin{array}{c}\text { Orthopedics } \\
\text {-Male }\end{array}$ & & 2 & 1 & & 2.0 & 1.5 & 1.0 & $\mathrm{x}$ & $\mathrm{x}$ & $\mathrm{x}$ & $\mathrm{x}$ \\
\hline Female & & 2 & 1 & & 1.0 & 2.0 & 0.1 & $\mathrm{x}$ & $\mathrm{x}$ & $\mathrm{x}$ & $\mathrm{x}$ \\
\hline O.T. & 1 & 2 & 2 & & 1.7 & 1.1 & 2.0 & $\mathrm{x}$ & $\mathrm{x}$ & $\mathrm{x}$ & $\mathrm{x}$ \\
\hline S.N.C.U & & 2 & 2 & & 0.4 & 2 & 1.0 & $\mathrm{x}$ & $\mathrm{x}$ & $\mathrm{x}$ & $\mathrm{x}$ \\
\hline Plastic Surgery & 1 & 1 & 1 & & 0.3 & - & - & $\mathrm{x}$ & $\mathrm{x}$ & $\mathrm{x}$ & $\mathrm{x}$ \\
\hline Neurosurgery-M\&F & & 1 & 1 & & 0.1 & 0.2 & & $\mathrm{x}$ & $\mathrm{x}$ & $\mathrm{x}$ & $\mathrm{x}$ \\
\hline O.T. & 1 & 1 & 1 & & & & & $\mathrm{x}$ & $\mathrm{x}$ & $\mathrm{x}$ & $\mathrm{x}$ \\
\hline Urology-M \& F & & 1 & 1 & & 1.5 & 1.5 & 1.0 & $\mathrm{x}$ & $\mathrm{x}$ & $\mathrm{x}$ & $\mathrm{x}$ \\
\hline O.T. & 1 & 1 & 1 & & 2.0 & 3.0 & 0.1 & $\mathrm{x}$ & $\mathrm{x}$ & $\mathrm{x}$ & $\mathrm{x}$ \\
\hline I.C.U. & & 1 & 2 & & 0.2 & 1.2 & 1.0 & $\mathrm{x}$ & $\mathrm{x}$ & $\mathrm{x}$ & $\mathrm{x}$ \\
\hline Eye-OPD & & 1 & 1 & & 0.5 & & & $\mathrm{x}$ & $\mathrm{x}$ & $\mathrm{x}$ & $\mathrm{x}$ \\
\hline O.T. & 1 & 1 & 1 & & & & & $\mathrm{x}$ & $\mathrm{x}$ & $\mathrm{x}$ & $\mathrm{x}$ \\
\hline Male\& Female ward & & 2 & 2 & & 0.1 & 0.4 & 03 & $\mathrm{x}$ & $\mathrm{x}$ & $\mathrm{x}$ & $\mathrm{x}$ \\
\hline ENT-O.P.D. & & 1 & 1 & & 0.3 & 0.3 & & $\mathrm{x}$ & $\mathrm{x}$ & $\mathrm{x}$ & $\mathrm{x}$ \\
\hline O.T. & 1 & 1 & 1 & & 1.2 & 0.6 & & $\mathrm{x}$ & $\mathrm{x}$ & $\mathrm{x}$ & $\mathrm{x}$ \\
\hline Male \& Female ward & & 2 & 2 & & 1.0 & 2.0 & 0.5 & $\mathrm{x}$ & $\mathrm{x}$ & $\mathrm{x}$ & $\mathrm{x}$ \\
\hline O \& G-Ward & & 6 & 3 & & 2.5 & 8.0 & 1.5 & $\mathrm{x}$ & $\mathrm{x}$ & $\mathrm{x}$ & $\mathrm{x}$ \\
\hline Labour room & 5 & 8 & 2 & 7 & 15.0 & 20.0 & 2.0 & $\mathrm{x}$ & $\mathrm{x}$ & $\mathrm{x}$ & $\mathrm{x}$ \\
\hline PP Centre & & 1 & 1 & & 0.1 & 0.1 & & $\mathrm{x}$ & $\mathrm{x}$ & $\mathrm{x}$ & $\mathrm{x}$ \\
\hline O.P. D. & & 1 & 1 & & 0.1 & 0.2 & & $\mathrm{x}$ & $\mathrm{x}$ & $\mathrm{x}$ & $\mathrm{x}$ \\
\hline O.T. & 2 & 5 & 1 & 1 & 3.0 & 0.3 & 0.5 & $\mathrm{x}$ & $\mathrm{x}$ & $\mathrm{x}$ & $\mathrm{x}$ \\
\hline Dental OPD & 1 & 1 & 1 & & 0.5 & 0.5 & & $\mathrm{x}$ & $\mathrm{x}$ & $\mathrm{x}$ & $\mathrm{x}$ \\
\hline Medicine OPD & & 1 & 1 & & 0.2 & 1.0 & 0.5 & $\mathrm{x}$ & $\mathrm{x}$ & $\mathrm{x}$ & $\mathrm{x}$ \\
\hline SPM OPD & & 1 & 1 & & 0.5 & 0.5 & & $\mathrm{x}$ & $\mathrm{x}$ & $\mathrm{x}$ & $\mathrm{x}$ \\
\hline T.B. Chest O.P. D & & 2 & 1 & & 1 & 0 & 0 & $\mathrm{x}$ & $\mathrm{x}$ & $\mathrm{x}$ & $\mathrm{x}$ \\
\hline
\end{tabular}

$\mathrm{Y}=$ Yellow, $\mathrm{B}=\mathrm{Black}, \mathrm{R}=\mathrm{Red}, \mathrm{PPC}=$ puncture proof container 
Table 2b

\begin{tabular}{|c|c|c|c|c|c|c|c|c|c|c|c|}
\hline \multirow{2}{*}{$\begin{array}{l}\text { Generating Points/Hospital } \\
\text { wards }\end{array}$} & \multicolumn{3}{|c|}{ No. of Bags } & \multicolumn{4}{|c|}{ Wt. in $\mathrm{KG}$} & \multirow{2}{*}{ Occupancy } & \multirow{2}{*}{$\begin{array}{l}\text { Segregated/ } \\
\text { Mutilated }\end{array}$} & \multirow{2}{*}{$\begin{array}{l}\text { Handed } \\
\text { over to } \\
\text { BMW }\end{array}$} & \multirow{2}{*}{ Signature } \\
\hline & $\mathbf{Y}$ & $\mathbf{R}$ & B & $\mathbf{Y}$ & $\mathbf{R}$ & B & PPC & & & & \\
\hline Dressing Room & & 2 & 1 & & 1.0 & 0.7 & & $\mathrm{x}$ & $\mathrm{x}$ & $\mathrm{x}$ & $\mathrm{x}$ \\
\hline $\mathrm{RDC}$ & & 5 & 5 & & 1 & 2.7 & 2.9 & $\mathrm{x}$ & $\mathrm{x}$ & $\mathrm{x}$ & $\mathrm{x}$ \\
\hline Blood Bank & & 6 & 4 & & 2.9 & 7.6 & & $\mathrm{x}$ & $\mathrm{x}$ & $\mathrm{x}$ & $\mathrm{x}$ \\
\hline Casualty \& emergency O.T. & 3 & 6 & 4 & & 5.0 & 3.0 & 2.0 & $\mathrm{x}$ & $\mathrm{x}$ & $\mathrm{x}$ & $\mathrm{x}$ \\
\hline Ortho OPD & & 1 & 1 & & 0.5 & & & $\mathrm{x}$ & $\mathrm{x}$ & $\mathrm{x}$ & $\mathrm{x}$ \\
\hline \multirow[t]{2}{*}{ Sickelcell Unit } & & 1 & 1 & & 0.2 & 0.1 & & $\mathrm{x}$ & $\mathrm{x}$ & $\mathrm{x}$ & $\mathrm{x}$ \\
\hline & & & & & & & & $\mathrm{x}$ & $\mathrm{x}$ & $\mathrm{x}$ & $\mathrm{x}$ \\
\hline Total & & & & 8 & 58.3 & 132.5 & 53.7 & $\mathrm{x}$ & $\mathrm{x}$ & $\mathrm{x}$ & $\mathrm{x}$ \\
\hline
\end{tabular}

$\mathrm{Y}=$ Yellow, $\mathrm{B}=\mathrm{Black}, \mathrm{R}=\mathrm{Red}, \mathrm{PPC}=$ puncture proof container

Table 3. Waste generated at various health care centre of Sambalpur and Burla transported to BWTF, V.S.S. Medical college Burla per day

\begin{tabular}{|c|c|c|c|}
\hline \multirow{2}{*}{ Name of Hospital: Private Health Units of Sambalpur \& Burla } & \multicolumn{3}{|c|}{ Wt. in $\mathrm{Kg}$} \\
\hline & PPC & $\mathrm{Y}$ & $\mathrm{R}$ \\
\hline Janani Maternity, Modipara & 1 & 4.7 & 1.9 \\
\hline Sanjivani Hospital, Modipara & 0.5 & 3 & 1 \\
\hline Jalan Nurshinh Home, Khetrajpur & 0.5 & 2.5 & 1 \\
\hline Sumitra Nurshing Home, Khetrajpur & 0.7 & 2.7 & 1 \\
\hline Astha Nurshing Home, Budha Raja & 0.5 & 4.7 & 1.9 \\
\hline Jyoti, Hopital Budharaja & 0.2 & 3 & 1 \\
\hline Srusti Nurshing Home, Budharaja & 1 & 3.5 & 1.5 \\
\hline Balaji Nurshing Home,Hospital road, SBP & 0.5 & 2 & 1 \\
\hline Ashirwad Nurshing Home, Hospital road, SBP & 1 & 1 & 1.2 \\
\hline Lifeline Diagnostic, Hospital road, SBP & 0.5 & 2.7 & 1 \\
\hline Basundhara Maternity, dhobipada, SBP & 0.4 & 3 & 1 \\
\hline Hariom Nurshing Home, Budharaja & 0.3 & 3 & 1 \\
\hline JMJ Hospital, NH Baraipali & 0.2 & 2 & 1.5 \\
\hline Amrita Health care, Majhipali, SBP & 0.2 & 4 & 1 \\
\hline Pratima Nurshing Home, NH Baraipali & 1 & 2 & 1.3 \\
\hline Seva Nurshing Home, Sakhipada, SBP & 0.3 & 3 & 1 \\
\hline Patel Nurshing Home, Burla & 1 & 2.9 & 1.3 \\
\hline Binayak Nurshing Home, Burla & 0.5 & 1.5 & 1.5 \\
\hline Ramachandi Nurshing Home, Burla & 2.5 & 1.4 & 0.9 \\
\hline Gupta Nurshing Home, Burla & 1 & 4.7 & 1.9 \\
\hline Samleswari Nurshing Home, Burla & 2.8 & 1.5 & 1.9 \\
\hline Gupta Diagnostic centre, Burla & 1.9 & 1.2 & 0.9 \\
\hline GouriShankar Nurshing Home, Burla & 0.5 & 3.7 & 1.9 \\
\hline Sparsh Nurshing Home, Sambalpur & 0.4 & 1.2 & 1.5 \\
\hline Rohini Diagnostic centre, Burla & 2.7 & 2.5 & 1.3 \\
\hline Sree Nurshing Home, Kamli Bazar, SBP & 0.5 & 1.5 & 1 \\
\hline Trilochan Netralaya, SBP & 0.2 & 3 & 2.2 \\
\hline Chakshusyam Eye clinic, Burla & 0.1 & 2.5 & 1 \\
\hline Samarpan Children Hospital, Sambalpur & 1 & 1.9 & 1 \\
\hline A. K. Clinic, Burla & 0.4 & 1.5 & 1.5 \\
\hline Nidan, Nurshing Home Burla & 1 & 2.5 & 1.5 \\
\hline Total Per day BMW generated & 25.3 & 80.3 & 32.8 \\
\hline Per year generation & 9234.5 & 29309.5 & 11972 \\
\hline
\end{tabular}


Further, the wastes generated in different health care centre of Sambalpur town which is $18 \mathrm{Km}$ away from the CBWTF are collected and transported to CBWTF for treatment and disposal. There are 31 health care centres at Sambalpur locality. All the health care centres transported the waste in three different colour coded bags i.e. ppc, yellow and red. From the analysis it was found that the total per day waste transported to CBWTF was $25.3 \mathrm{~kg}, 80.3 \mathrm{~kg}$ and 32.8 $\mathrm{kg} /$ day in PPC, yellow and red bags respectively (Table.3)

To find the greenhouse gas emissions from the transportation of medical waste 2010 Guidelines to Defra / DECC's GHG Conversion Factors for Company Reporting [26] is used. The estimated distance covered by the vehicle used for transportation of biomedical waste from different government and private health care unit located in and around Sambalpur and Burla town to the CBWTF at V.S.S. Medical College is $50 \mathrm{KM} /$ day

Total distance travelled by truck in a single day $=50$ $\mathrm{kms} \times 2$ (no. of vehicles) $=100 \mathrm{Kms}$

Consumption of fuel $=20$ litres of diesel per day $=20 \times 365$ $=7300$ litres per year.

The total emissions was found to be $23,204.51 \mathrm{~kg}$. The calculation of GHG emissions using emission factors is explained in Table 4.

Table 4. Total GHG emissions during BMW management

\begin{tabular}{|c|c|c|c|}
\hline $\begin{array}{c}\text { Types of } \\
\text { emission }\end{array}$ & $\begin{array}{c}\text { Conversion } \\
\text { Factor (CF) }\end{array}$ & $\begin{array}{c}\text { Units of } \\
\text { diesel (litres) }\end{array}$ & $\begin{array}{c}\text { Resulting } \\
\text { emissions in } \\
\text { Kg CO } \text { eq }_{2} \\
\mathrm{CF} \mathrm{x} \mathrm{Units}\end{array}$ \\
\hline $\begin{array}{c}\text { Direct } \\
\text { emissions }\end{array}$ & 2.6413 & 7300 & 19281.49 \\
\hline $\mathrm{CO}_{2}$ & 0.0015 & 7300 & 10.95 \\
\hline $\mathrm{CH}_{4}$ & 0.0292 & 7300 & 213.16 \\
\hline $\mathrm{N}_{2} \mathrm{O}$ & 0.5067 & 7300 & 3698.91 \\
\hline $\begin{array}{c}\text { Indirect } \\
\text { emissions }\end{array}$ & \multicolumn{3}{|c|}{ TOTAL EMISSIONS } \\
\hline \multicolumn{3}{|c|}{} \\
\hline
\end{tabular}

\section{Waste Management Practices in V.S.S. Medical College Burla}

The plastic bins as per the norms are kept in each facilities and the waste are collected and transferred to the Biomedical Waste Management Facility.: The wastes were segregated into various categories of waste like incinerable waste and recyclable waste depending upon its composition and properties. The plastics and other glass wares were however recycled immediately and were not stored anywhere as in case of other biomedical waste stored in bins. The waste so generated is stored in drums for a period of 10-15 days and then it is treated after a bulk in heaped. Three separate devices has been installed and used for BMW management.(a)Incinerator(b) Microwave and (c) Shredder.

The capacity of the Incinerator is $70 \mathrm{Kg} / \mathrm{hr}$ and the height of the chimney is $100 \mathrm{ft}$. through which the gases exhaust to the atmosphere. (Table. 5). There is a facility for cooling and the waste water generated during the process is released directly to the drain. The running time of the incinerator is between $8.30 \mathrm{AM}-1.30 \mathrm{PM}$ depends upon the amount of waste collected. Mostly the anatomical and solid based waste has been treated in incinerator. The ashes generated by the process are dumped in sanitary landfill. The microwave installed in the CBWTF has the capacity of $100 \mathrm{Kg} / \mathrm{hr}$. the solid based waste has been treated through microwave to disinfectant the waste and after that the waste has been send for auction. Similarly, the shredder installed in BMW unit of V.S.S Medical has the capacity of $100 \mathrm{Kg} / \mathrm{hr}$. The shredder has been used for cutting the plastics. After disinfectant by microwave the plastics were send for auction for recycle.

Table 5. the operating and emission details of the incinerator

\begin{tabular}{|c|c|c|}
\hline Parameters & $\begin{array}{l}\text { Existing in } \\
\text { CBWTF }\end{array}$ & Permissible limits \\
\hline $\begin{array}{l}\text { Incineration standards } \\
\text { Combustion efficiency }\end{array}$ & $90 \%$ & $99.0 \%$ \\
\hline $\begin{array}{l}\text { temperature of the } \\
\text { primary chamber }\end{array}$ & $850^{\circ} \mathrm{C}$ & $800 \pm 50^{\circ} \mathrm{C}$ \\
\hline $\begin{array}{l}\text { Temperature of the } \\
\text { Secondary Chamber }\end{array}$ & $1050^{\circ} \mathrm{C}$ & $1050 \pm 50^{\circ} \mathrm{C}$ \\
\hline $\begin{array}{l}\text { emission standards } \\
\text { 1.Particulate matter } \\
\text { 2. Nitrogen Oxides } \\
\text { 3.HCL }\end{array}$ & & $\begin{array}{c}\frac{\text { Concentration } \mathrm{mg} / \mathrm{Nm}^{3}}{\left(\frac{\mathrm{a}_{0}\left(12 \% \mathrm{CO}_{2}\right.}{\text { correction })}\right.} \\
150 \\
450 \\
50 \\
\end{array}$ \\
\hline Minimum stack height & $100 \mathrm{~m}$ & $30 \mathrm{~m}$ above ground \\
\hline
\end{tabular}

\section{Discussion}

There are no reliable data available of the quantum of waste generated per person per day either in indoors or out door patient in Indian Hospital particularly in Odisha. Even there is no uniformity in the data on the quantum of biomedical waste being generated. From the data available from Armed Forces Medical College where the average daily waste generated of anatomical waste is $5.6 \mathrm{~kg}$, Animal tissue waste $7.1 \mathrm{~kg}$, Micro and Biotechnological waste $5 \mathrm{~kg}$, Discarded medicines and cytotoxic drugs nil, waste soiled $9.5 \mathrm{~kg}$, solid waste $149 \mathrm{~kg}$, liquid waste 73 litres, incinerator ash nil, chemical waste $7.1 \mathrm{~kg}$, waste sharpes not assessed [27]. In the present study the average daily waste particularly the anatomical waste shows high quantity i.e. $40-50 \mathrm{~kg} /$ day, the waste sharps generation shows $30-40 \mathrm{~kg} /$ day. The variation in the quantum of waste generation differs not only from country to country but also within the country which depends on the type of health care establishment, hospital specialization, proportion of reusable items employed in the health care centres and proportion of patients treated on a day-care basis.

According to WHO, the hazardous waste in an hospital is around $10-25 \%$ of the total health care waste. This study shows that the medical waste generated at V.S.S. Medical College is $49 \%$ of the total health care waste produced in the hospital, which clearly states that the current segregation practice is not that efficient in reducing the waste going to 
incinerator. According to the opinion of employees at V.S.S.Medical College and hospital Burla, the important reasons for the improper segregation of wastes are; inappropriate location of waste bins, waste bins being full and lack of knowledge regarding the constituents of medical waste. Thus the study shows that the waste management activities at the V.S.S.Medical College and hospital have to be improved.

The knowledge about the constituents of medical reason is generally considered as one of the main barrier towards proper medical waste management [,28]. But the study shows that the health care workers at V.S.S.Medical College and hospital seemed to be aware about the constituents and the hazardous nature of medical waste. This may be because of the familiarity of health care workers with syringes and needles and also with accidents that happen as a result of sharps injury $[29,30]$. Some confusion does exist among workers especially about chemicals, unused medicines and pressurized containers. These confusions can be avoided by proper training. But these wastes account for only a small amount of the medical waste and cannot be assumed as the reason behind higher generation of hazardous waste. One of the reasons behind inefficiencies in the sustainable waste management practices are related to the behavior of individuals [31]. Considering the fact that most of the workers have enough knowledge about the constituents of medical waste and employees being satisfied with the current waste management practices, it can be interpreted from the study that there is a value - action gap between their intended behaviour and actual practice towards waste management. Lack of incentives, awareness of recycling provision and apathy have crucial role in framing such behaviour [32]. Appropriate facilities, opportunities to put right waste in the right bin, convenience, time and space are some of the factors affecting this behaviour $[33,34]$.

Various studies shows that due to the high capital and maintenance cost involved, developed countries are bringing an end to the incinerators and are investing more on the alternative treatment technologies impact $[35,36,37,38,39,40]$. Well the argument is true for municipal waste, but for medical waste when considered from the hospitals perspective, incineration seems to be a better option from the available technological alternatives.

As V.S.S. Medical college is a very big hospital with almost every health care facilities it was important that the on site treatment plant selected should treat all the types of waste. Incinerator is not a very bad idea if the future energy requirements and the potential long-term health effects are considered along with the environmental impacts[41]. If properly handled and proper segregations are done, incineration would be the suitable method to treat clinical waste $[13,1]$. There has been an increase in public concern about the medical waste management over the years [1].There has been a wide protest against the incineration plants around the globe $[42,43]$.

\section{Conclusions}

The study presents the status of existing CBWTF at V.S.S. medical college \& Hospita, Bural Odisha, India. An appropriate strategy for safe management of BMW has been taken up integrating technical, financial, institutional, managerial, social and environmental issues. The technology used in CBWTF is a combination of incineration, microwave, shredder and secured landfill. The unit started operation in 2006. All the BMW generators are yet to get enrolled to utilize this off-site facility. The facility has to face problems while burning BMW, as many BMW generators do not adhere to the rules of segregation in to the container bags at the point of generation and are ot labeled according to Schedule III of BMW (Management and Handling) Rules, 1998. The performance of CBWTF can be enhanced with cooperative efforts of BMW generators possible if a healthy co-ordination exists between CBWTF and BMW generators.

\section{Acknowledgements}

The support of Dr. S. K. Swain and the officials of Superintendent Office as well as the staffs of CBWTF of V.S.S. Medical \& Hospital during investigation of the present study is highly acknowledged.

\section{REFERENCES}

[1] Al-ZahraniM.A, Fakhri ZI,Al-Shanshouri MA, Al-Ayed MH : Healthcare risk waste in Saudi Arabia. Rate of generation. $J$. Saudi Med 2000,21:245-250.

[2] ArmstronBA,Reinhardt PA : "Managing laboratory biomedical waste using a large on-site autoclave-shredder." Journal of Chemical Health and Safety 2010, 17(8):33-39.

[3] Barr S, Gilg A, Ford N: Defining the multi-dimensional aspects of household waste management: a study of reported behaviour in Devon. Res Conserv Recycl, 2005, 45(2):17292.

[4] Batterman S : Findings on an Assessment of Small-scale Incinerators for Health-care Waste. Water, Sanitation and Health Protection of the human environment. World Health Organization Geneva, 2004, 01-07.

[5] Chauhan Maya Singh, Kishore Malviya : Existing solid waste management in hospitals of Indore city. Indian J. Environ. Sci 2002, 6: 43-49.

[6] Christmann W, Hasiske D, Kloppel K.D, Partscht H, Rotard $\mathrm{W}$ : Combustion of polyvinylchloride - an important source for the formation of PCDD/PCDF. Chemosphere 1989, 19: 387-392.

[7] Cisse C T,Faye O, Ndiaye G, Sakho A,Faye EO,Maiga A, Wade F,Sy-Ngom K, Gueye M,Zino J M, Diadhiou $\mathrm{F}$ :Prevention of infection in a surgical environment in the regional hospitals of Senegal. Sante 2000, 10: 189-194. 
[8] Danish Environmental Protection Agency (Danish EPA): PVC and Alternative Materials (English translation). Danish Environmental Protection Agency 1993. Strandgade 29, DK 1401 Copenhagen K, Denmark.

[9] Defra: Guidelines to / DECC's GHG Conversion Factors for Company Reporting: Methodology Paper for Emission Factors. 2010.

[10] Dilly GA, Shanklin CW: Solid waste management practices in U.S. Army medical treatment facilities. Mil Med 2000, 165:302-304.

[11] Dursun Mehtap, E,Ertugrul Karsaka, Melis Almula Karadayi: Assessment of health-care waste treatment alternatives using fuzzy multi-criteria decision making approaches. Resources, Conservation and Recycling 2011, 57 , 98-107

[12] Eriksson E, Anderson HR, Ledin A: Substance flow analysis of parabens in Denmark complemented with a survey of presence and frequency in various commodities. $J$. Hazardous materials 2008, 156: 240-259.

[13] Henry K, Campbell S, Collier P, Williams CO: Compliance with universal precautions and needle handling and disposal practices among emergency department staff at two community hospitals. Am. J. Infect. Control 1994, 22: $129-137$

[14] HuSW, Shy CM:Health effects of waste incineration: A review of epidemiologic studies. Journal of the Air and Waste Management Association 2001, 51: 1100-1109.

[15] Jagger F, Hunt EH, Brand-Elnaggar J,Peasron RD:. Rates of needle-stick injury caused by various devices in a university hospital. N Eng J Med, 1989, 319(5):284-288.

[16] James R : Incineration: why this may be the most environmentally sound method of renal healthcare waste disposal. J Ren Care 2010,36(3):161-9.

[17] Jang YC, Lee C, Yoon OS, Kim H: Medical waste management in Korea. Journal of Environmental Management 2006, 80: 107-115.

[18] Kanters M, Louw R.: Final report of the RUL-VROM project: GFT, PVC, Afvalverbranding en 'Dioxine' (Green Waste Fraction, PVC, Waste Incineration and 'Dioxins'). Leiden: Centre for Chemistry and the Environment. Department of Chemistry, University of Leiden, 1993, report number 93-09.

[19] Karagiannidis A, Papageorgiou A, Perkoulidis G, Sanida G, Samaras P: A multi-criteria assessment of scenarios on thermal processing of infectious hospital wastes: a case study for Central Macedonia, Waste Management 2010, 30 : 251262.

[20] Kishore J, Goel P, Sagar B, Joshi TK: Awareness about biomedical waste management and infection control among dentists of a teaching hospital in New Delhi, India. Indian J. Dent. Res. 2000, 11: 157-161.

[21] Kopponen P, Torronen R, Ruuskanen J,Tarhanen J,Vartiainen T, Karenlampi S: Comparison of cytochrome P4501A1 induction with the chemical composition of fly ash from combustion of chlorine containing material. Chemosphere 1992,24 (4): 391-401.

[22] Lee WJ, Liow M.C,Hsieh L T,Chen IJ, Tsai P J: Impact of polycyclic aromatic hydrocarbon emissions from medical waste incinerators on the urban atmosphere. Journal of the
Air and Waste Management Association 2003,53: 1149-1157.

[23] Linde MK : Hazardous materials management and control in clinical laboratories of small hospitals. Clin. Lab. Manage. Rev. 1993, 7: 493-496.

[24] Liorente Alvarez S, Arcos Gonzalez P, Gonzalez Estrada R: The evaluation of hospital management of sanitary waste in the principality of Asturias. Rev.Esp. Salud. Publica. 1997, 71:189-200.

[25] Liss GM, Crimi C, Jaczek KH, AndersonA., Slattery B,D'Cunha C:Improper office disposal of needles and other sharps: an occupational hazard outside of health care institutions. Canadian Journal of Public Health, 1990, 81: $417-420$

[26] Lopes WS, Duarte L,Shiva P : Influence of inoculum on performance of anaerobic reactors for treating municipal solid waste, Bioresource Technology 2004, 94: 261-266.

[27] Singh Zile. Bio-medical waste Management in teaching Hospital: An experience. Journal of ISHWM 2003,2(1): 20-27.

[28] Marinkovic N, Vitale K, Holcer NJ,Dzakula A, Pavic T: Management of hazardous medical waste in Crotia. Waste Management2008, 28: 1049-1056.

[29] PATH : Treatment Alternatives for Medical Waste Disposal Seattle, 2005. WA 98107-5136 USA. www.path.org

[30] Rand T, Hankohl J, Marxen U: Municipal Solid Waste Incineration, A Decision Maker's Guide. World Bank, Washington, DC. 2000

[31] Robinson GM, Read AD: Recycling behaviour in a London borough: results from large-scale household surveys. Res Conserv Recycl 2005, 45: (1):70-83.

[32] Rootes C: Explaining the outcomes of campaigns against waste incinerators in England: community, ecology, political opportunities and policy contexts. Research in Urban Policy, Vol. 10, special issue on Community and Ecology, Aaron McCright and Terry Nichols Clark (eds.), 2006 : 179-198.

[33] Saini S, Nagarajan SS, Sharma RK: Knowledge, attitude and practices of biomedical waste management amongst staff of a tertiary level hospital in India. $J$ of Academy of Hospital Administration2005, 17(2): 1-12

[34] Saini S, Das BK, Kapil A, Nagarajan SS, Sarma RK:(2004). The study of bacterial flora of different types in hospital waste: Evaluation of waste treatment at AIIMS Hospital, New Delhi. Southeast Asian Journal of Tropical Medicine and Public Health 2004, 35(4): 986-989.

[35] Sharma V, Sharma A, Bansal R K:A study of disposal of hospital wastes in a rural teaching hospital. J. Acad. Hosp. Adm. 1993, 5: 43-46.

[36] Shinee E, Gombojav E, Nishimura A, Hamajima N, Ito K: Healthcare waste management in the capital city of Mongolia. Waste Management 2008, 28: 435-441.

[37] Thiessen J: Untersuchung der Moglichen Umweltgefahrdung Beim Brand Von Kunststoffen (Investigation of Possible Environmental Dangers Caused by Burning Plastics). Berlin: German Umweltbundesamt Bismarkplatz 1, 1000 Berlin 33, Germany, Report 1991, 104-09-222,

[38] Tonglet M, Phillips PS, Read AD: Using the theory of 
planned behaviour to investigate the determinants of recycling behaviour: a case study from Brixworth, UK. Res Conserv Recycl 2004, 41(3):191-214.

[39] Tucker P: Understanding recycling behaviour. University of Paisley Environmental Technology Group Research Report, 2001 vol. 2. UK: University of Paisle .

[40] UNEP: International Source Book on Environmentally Sound Technology for Municipal Solid Waste Management. United Nations Environmental Programme, United Nations, 1996 ISBN: 9280715038.
[41] WHO: Starting health care waste management in medical institutions. Health Care Waste Practical Information Series 1 2000.

[42] Yu-Min-Chang: Centralized incineration treatment of infectious waste for regional hospitals in Taiwan, Bio-medical management proceedings 1993.

[43] Zhao L, Zhang FS, Hao Z, Wang H: Levels of polycyclic aromatic hydrocarbons in different types of hospital waste incinerator ashes. Science of the Total Environment 2008, 397: 24-30. 